\title{
BUNG KARNO AND THE FOSSILIZATION OF SOEKARNO'S THOUGHT
}

\section{Benedict R. O'G. Anderson}

Not long after Bung Karno died [June 21, 1970], I received a letter from a friend. He had been enraged with the Great Leader of the Revolution, and had actively resisted Guided Democracy because he felt that both institutions were authoritarian, had ruined the Indonesian economy, had further impoverished the little man, and had given the Indonesian Communist Party the green light. But in the letter he told me how astonished he had been when, watching Bung Karno's funeral cortege passing solemnly along the main streets of Jakarta, he had suddenly broken down into sobs. My friend did not explain why these tears poured down his cheeks. But I suspected that deep down he loved Bung Karno while at the same time was bitterly disappointed by all that he had done wrong.

\footnotetext{
" In the summer of 2001, when newspapers, magazines, and organizations were commemorating the centennial of Soekarno's birth, I was encouraged by some Indonesian friends to make my own small contribution. Recognizing that I belonged to a very small group of Indonesianists old enough to have lived under Soekarno's rule and seen him in the flesh on many occasions, I decided to use my life-experience in the writing. The text grew and grew till it was far too long for the Indonesian media; so it was finally published in mini-pamphlet form, at the cheapest possible price, for sale in bus stations, street corners, local markets. For this opportunity, I want to thank Arief Djati and his wonderful, tiny Bamboe Roentjing Press. The readers I wanted to reach were not middle-class Djakarta intellectuals, but ordinary people, especially the young. So the text was written in a relaxed, colloquial Indonesian, spiced with some jokes and ironical allusions. At the request of some American friends, I have translated it into English here, not without difficulty. The Indonesian original had no footnotes, and I think needed none. But for younger nonIndonesian readers, perhaps some of the allusions are today obscure enough to require explanation. These are provided in two forms: if they are very short, they are included in the text in square brackets; if longer than that, as footnotes.
} 
Today, more than thirty years later, it is very likely that there is no one any more who is angry with Bung Karno. The old rage has dispersed, overwhelmed and swept away by tidal waves of newer and still more bitter rage. But the love has never been extinguished, except that sometimes it has turned into idolization, as if Bung Karno were a kind of god or maharaja, not merely an ordinary human being who was also extraordinary. As a result, some of his ideas, which were still fresh when he first launched them, have gradually become fossilized "teachings," believed to be immune to the ravages of Batara Kala [The demonic, ravenous God of Time, in wayang]. In this way, the fate of Bung Karno's thinking mirrors the fossilization undergone by the ideas of Kyai Hadji Dahlan, the pioneer of modernist Islam in Indonesia, Vladimir Lenin, pioneer of the Marxist world-revolution, St. Paul, pioneer of the globalization of Christianity, and of many others. In the face of the present enormous crisis, surely all kinds of fossilized thinking are extremely dangerous. But also incense-scented love.

Although Bung Karno was not the avatar of a divinity, it must still be recognized that the course of his life was largely shaped by the Goddess of History, whose streetname is Miss Suppose-That. Suppose that Bung Karno had been born in 1881, not in 1901. It would have been impossible then for him to attend a HBS, the very best type of high school in the Indies, or to be a member of the first class of graduates from Bandung's Institute of Technology, or even, perhaps, to become President of Indonesia in 1945-since by then he would have been sixty-four years old, which for an Indonesian in those days was very old indeed. Born in 1901, he had the good fortune to become the heir of the great pioneers of liberation movements in Asia and the Near East. José Rizal, national hero and martyr of the Philippines, born in 1861, was executed by the Spanish colonial regime five years before the baby Soekarno first saw the light of day. Sun Yat-sen, the great founding father of Chinese nationalism, was born in 1866 and died two years before Bung Karno founded his Indonesian National Party (PNI) in 1927. Mahatma Gandhi, born in 1869, was a world-famous figure when Bung Karno still had snot dripping from his little-boy nose. Kemal Pasha (Ataturk), born in 1881, became president of the nation-state of Turkey when Bung Karno was enjoying teenage life in high school. (And Bung Karno was only four years old when Japan became the first Asian state to win a military victory over a European power, in this case imperial Russia.) Bung Karno revered all these leaders, learned from their struggles, and so came to feel that Indonesia's fight for independence had to be made part of the fight for emancipation throughout the colonial world. Here was sown the "global" consciousness that later bloomed in the form of the Bandung Conference of Non-Aligned Nations in 1955 and his own concept of the New Emerging Forces.

Miss Suppose-That had still another role to play which ought to be mentioned here. "By chance" the first Marxist revolution exploded in St. Petersburg when Bung Karno was still "sweet sixteen," a time of life which is usually full of idealism, dynamism, and romanticism. Even as an old man, Bung Karno was still fond of talking about the "romanticism" of revolution-a language very different from that of younger Indonesian Marxists like Aidit, Lukman, Njoto, and Sudisman [the top leaders of the

\footnotetext{
${ }^{1}$ Hoogere Burgerschool. These Dutch-language high schools were originally intended only for the children of Dutch colonials and had standards equivalent to the best high schools in Holland. Only gradually were small numbers of privileged natives and peranakan Chinese permitted to attend. Soekarno was enrolled at the HBS in Surabaja.
} 
PKI, Indonesian Communist Party after 1951], who came of age when the Bolshevik movement of 1917 had begun to fossilize under the cruel dictatorship of Josef Stalin. In the 1920s, being a Marxist did not yet automatically mean being a member of any particular political apparatus. It simply meant being open to the inspiration of Karl Marx's and Vladimir Lenin's penetrating analyses of global capitalism and imperialism, and actively participating in practical politics. In this regard, Bung Karno was absolutely not unique. To varying extents, his entire political generation was influenced by this Marxist vision. For them, socialism was like a sun magnificently emerging on the world's horizon. But "supposing that" Bung Karno had been born in 1881, he would not have thought this way; and if born in 1921, by the time he would have come of age "socialism" was no longer a general dream but was becoming the political monopoly of particular organizations.

"By chance," too, he was born to a low-level Javanese priyayi and a young woman from the Island of the Gods (which had then only just passed fully into the clutches of Dutch imperialism [Southern Bali finally succumbed in 1906]. In that era "mixed children" were relatively rare among the native population, and even more so among the small educated minority. Other leading figures of his generation were almost all pure Minangkabau, unblemished Javanese, Sundanese from time out of mind, and so on. Perhaps only the peranakan [typically of mixed Chinese and native descent, and no longer familiar with any written Chinese] were then used to being "mixed," both by descent and by culture. One can guess that his family background allowed Bung Karno to liberate himself very quickly from all kinds of narrow-minded ethnicism, and thus to embrace a very broad conception of nationalism. Yet it is also likely that his "mixed origins" also opened his eyes to the need for the healthy development of the cultures and autonomies of the many regions in the gigantic archipelago we call Indonesia.

One other "chance" proved no less important. It is a historical irony that the marriage which gave birth to Bung Karno has today become-with the recent Marriage Law-if not quite an impossibility, certainly a big hassle. ${ }^{2}$ So one could say that the emergence of Bung Karno into this fleeting world was possible only in a period when syncretism was still the norm in the Archipelago, and there were as yet no high, forbidding walls between different social groups. A fine indication of the depth of this syncretism is that the abortive Communist uprising of 1926-27 exploded in Banten and West Sumatra, both famous for the Islamic piety of their populations. Hence the syncretistic features of Bung Karno's thinking were nothing out of the ordinary, but characterized most of the native cultures of Indonesia at that time.

To see just how crucial were the cultural norms of the Archipelago in that era for "making possible" Bung Karno's political career, one has only to turn to the fate of Mahatma Gandhi and his Big Indian nationalism. Putting the matter quite crudely, one could say that Islam entered Big India on the sword-points of invaders from Afghanistan. From the thirteenth to the middle of the nineteenth century the most important kings and much of the ruling classes belonged to the Muslim minority, while the great majority of the common people remained Hindu. But British imperialism finally abolished the Muslim Mughal dynasty and gradually constructed a new

\footnotetext{
${ }^{2}$ In the original Indonesian version of this essay, I used deliberately the slangy Javanese word "angèl" rather than the standard Indonesian "sukar."
} 
political system based on electoral representation. Understandably these drastic changes angered the former ruling groups who feared losing all their privileges and becoming an ordinary minority. Here was the source of ever-increasing social antagonisms that in the end split Big India into two separate independent states, Smaller India and Pakistan, to the accompaniment of mass mutual slaughter between Muslims and Hindus. Although Gandhi was a good Hindu, he had a broad and humane vision, and did everything he could to prevent these calamities-with the result that he was assassinated by a fanatical terrorist who regarded the great man as a traitor to the Hindu community.

In Indonesia, on the other hand, Islam entered gradually, and, on the whole, peacefully, via individual preachers and seafaring traders. Gradually, too, the old Hindu-Buddhist monarchies disappeared, or converted to Islam, and the official institutions of the old religion vanished into the night. But in this centuries-long process, syncretism was always salient. Animistic and Hindu-Buddhist beliefs remained strong, as evidenced by the deep popularity, even today, of stories from the Mahabharata and the Ramayana, not only among the Javanese, but also among the Sundanese, Balinese, and Madurese, and even on the Malay Peninsula. The result of this steady syncretism was that there was no high religious wall separating rulers and ruled. In recruiting his armies, Prince Diponegoro could calmly utilize the symbols both of Islam and of Javanese mysticism. In the nineteenth century, only the bloody Paderi wars $^{3}$ in West Sumatra were marked by adversaries of clearly antagonistic religious orientations. Thus it was that Bung Karno, at least in his salad days, could pursue his syncretic political vision, open to elements of all religions, without meeting the Mahatma's personal and political fate. To the last moment of his life, the integrity of the Republic of Indonesia remained firm.

Nonetheless, in the long run, the Indonesia of his youth could not escape changes which gradually undermined the old syncretic cultures. Social compartmentalization steadily increased. Both Muslim and Christian missionaries worked hard to eliminate everything that seemed to them "superstitious" residues from a "primitive" past. The rapidly expanding secular education system of the state also "cornered" and marginalized the older ways of seeing the world. As literacy spread, more and more people read printed tracts glorifying "international norms and criteria." The traditional kyai (learned Islamic scholars) were forced little by little to give way to journalists and other intellectuals espousing a modernist Islam purified of "superstition." Marxists too were more and more inclined to dispense with people like Hadji Misbach, Semaun, and Tan Malaka, and to follow either Moscow's or Peking's "international line." And in the era of Harto every Indonesian was legally compelled to adhere to a "religion with a Book" (i.e. internationally "standard"), while syncretic belief-systems were, so to speak, kicked out of the official arena.

\footnotetext{
${ }^{3}$ Three Minangkabau pilgrims to Mecca, who happened to be in the city when it fell to the austere, fundamentalist Wahhabi movement at the end of the eighteenth century, became converted. On their return to West Sumatra in 1803 they began a three-decade long, partly successful, armed struggle to wipe out the syncretic Islam till then prevailing there.

${ }^{4}$ A devout Muslim and returned pilgrim from Mecca, Misbach was a staunch communist in the 1920s; Semaun and Tan Malaka were the first and second natives to head the Indonesian Communist Party, and both were later repudiated by the party apparatus.
} 
Bung Karno struggled might and main to dam the tide of de-syncretization, but not always in a wise manner. In reaction to Sekarmadji Kartosuwirjo's Darul Islam rebellion, ${ }^{5}$ the horror of the Tjikini Affair, ${ }^{6}$ the deadlock in the Constituent Assembly, and the PRRI, ${ }^{8}$ Soekarno became increasingly suspicious of modernist Muslims, without sufficiently distinguishing between moderates and hardliners. On the other hand, he was fond of the Nahdlatul Ulama and its syncretistic Islam. The total ban he imposed on the Masyumi proved to be a rash and vain policy which had dire consequences in the longer run. Even in the case of the PKI, he was wary of standardization. He made the murdered Tan Malaka, bogeyman to Aidit's PKI, a National Hero. ${ }^{9}$ And in the last years of his rule, it became obvious that Bung Karno particularly liked Njoto, whom he regarded as the most flexible and "syncretistic" of the PKI leaders. Rumor even had it that he wanted Njoto (who was then facing serious trouble inside his party ${ }^{10}$ ) to start a new Marxist (syncretic-nationalist) party in competition with the "standardized" PKI. Yet in the end all these endeavors collapsed in the catastrophe of 1965-66, which reminds us of the catastrophe experienced by Gandhi twenty years earlier.

All the same, we must also bear in mind that although Bung Karno was a legatee of the old, indigenous syncretism, he was also a modern politician, with the consequence that in his hands syncretism took on a new form, a good deal less syncretistic than its forerunners. This transformation is quite plain in his justly famous colonial-era work, Nationalism, Islam, and Marxism. The title itself, let alone the content, shows that in his eyes Islam and Marxism were "boxes," in other words, walled communities. Thus Islam was just that, Islam, without any local variations, Marxism was also just that, Marxism without local variation. The compartmentalism of these "boxes," he thought, had to be "overcome" in a highly conscious and sober-minded manner: thus a "planned," rather than a natural syncretism. The instrument at hand for the task of "overcoming" was to be a broad and deep nationalism. Marhaenism-I suspect that it was no accident that the term almost rhymed with Marxism-was always described by him as Marxism adapted to Indonesia's unique conditions. These ideas were launched at the "perfect time." The PKI was in ruins after its failed rebellion against

${ }^{5}$ Calling for Indonesia to become an Islamic state, this rebellion, centered in West Java and the western fringe of Central Java, lasted from 1948 to 1963.

${ }^{6}$ Tjikini Affair: a deadly grenade attack on Soekarno on November 30, 1957 while he was visiting his children's school in the Tjikini neighborhood of Jakarta. The President himself escaped unharmed, but eleven people, mostly school children died, and thirty others were seriously wounded. Later, a group of Islamic radicals, mostly from Bima on the island of Sumbawa, were tried and convicted for the outrage.

${ }^{7}$ Elected in 1955, the Assembly was supposed to draw up a permanent new constitution for Indonesia, but its work was paralyzed by conflicts between the major Islamic parties and the National Party, the Communist Party, and the various Christian minority parties.

${ }^{8}$ PRRI: the Revolutionary Government of the Republic of Indonesia, proclaimed in West Sumatra in February 1958 in opposition to the central government in Jakarta. The leaders were a loose coalition of ambitious, discontented military officers, both Muslim and Protestant, individual leaders from the anticommunist Masyumi (modernist Islamic) and Socialist parties, and regional notables.

9 Tan Malaka was executed by elements in the East Java military in February 1949, while he was attempting to rally the nation in the wake of the Dutch military's capture of Soekarno and Hatta.

${ }^{10}$ It is credibly reported that Njoto had become entangled with a Russian girl and was planning to divorce his wife. 
the colonial state; and the once-mighty Sarekat Islam (Islamic League) was in its death throes, to be replaced by a welter of smaller, often rivalrous, Muslim organizations.

In this grand endeavor, Bung Karno was lucky enough to get a windfall from Miss Suppose-That. In the 1930s President Manuel Quezon of the Philippines bemoaned the fact that 150 kilometers north of Manila, he needed an interpreter to talk to the local Ilocano-speaking voters. When he came to power in 1949, Mao Tse-tung's radio speeches could not be understood by the majority of the Chinese people, because he used Mandarin (the language of Peking and its environs) with a thick Hunan accent. Mahatma Gandhi had exactly the same experience. But in the Dutch East Indies, things were very different. In the seventeenth and eighteenth centuries, the VOC was too stingy, and in the nineteenth century The Netherlands was too poor, too small, and too unimportant, to impose the Dutch language on the Archipelago, in the way that English was imposed on Big India, and French on Senegal and the Ivory Coast. For these reasons, from early on the colonialists used a pidginized Malay as the administrative language throughout the areas they controlled. At the end of the nineteenth century this pidgin was increasingly standardized to fit the needs of modern schooling for the natives. Meanwhile, a kind of bazaar Malay was developing speedily in the world of the press, pioneered by Eurasians and peranakan Chinese (who were the true pioneers of modern Indonesian literature). Although there were also newspapers and magazines which used various regional languages, including Javanese, by the time Bung Karno graduated from his HBS high school, Malay was coming out decisively on top both within the bureaucratic apparatus and in the open market. Still better, and even more "by chance," this victorious language was not the personal property of any major ethnic group in the Archipelago. Hence it was very easy for it to become the National Language (that is, if the role of Grandfather VOC could be forgotten). "By chance" again, among Bung Karno's many talents none was more characteristic than his gift for oratory. Thus he endeavored with all his powers to take advantage of this windfall from the Goddess of History to spread the national language in every direction of the compass; and, simultaneously, with alluring, exciting, humorous, and heart-rending words, to invite the natives to transform themselves and their consciousness and thus to become members of the new Indonesian nation. With his resonant sweet voice Bung Karno demonstrated his love for his fellow-Indonesians (not for the natural resources of their respective ancestral lands), and also asked them to love him as their leader and the spokesman of their aspirations. Since this voice could be heard even by the illiterate majority of the natives, national solidarity grew ever wider and stronger. One might therefore say that Bung Karno was the perfect leader for the age of radio.

During the two decades between what white people ${ }^{11}$ like to call The First and The Second World War, it became very evident that in South and Southeast Asia there was a critical difference between the policies of the English-speaking imperialists and those of the users of French and Dutch. In Uncle Sam's Philippines, a cacique democracy, run by oligarchs on the basis of an electoral system with a highly restricted suffrage, began to be established as early as the 1900s. By the 1930s there was already an (Eurasian) president, and independence was promised for 1945. In Big India-which till the

\footnotetext{
${ }^{11}$ I used the jocular, slangy term "bulé" here. It is a curious experience for me to find this word, which literally means "albino," now so widely used for "white people" that everyone assumes it is old. I remember inventing it on a trip to Central Java in 1963, to my Indonesian companions' half-shocked amusement.
} 
middle 1930s included Burma-elections were already institutionalized and the seeds of democracy quite widely sown. After Burma was separated from Big India in 1937, three successive natives became Prime Minister before the country was invaded by the armies of Hirohito. Although London had made as yet no promises of independence, a trend in that direction was quite apparent. On the other hand, in The Netherlands Indies and in French Indochina there were no meaningful elections, and both had become police states, in which eventual independence was the last thing on the colonial rulers' minds. As a result both zones became fertile fields for the idea of "revolution," and for political activity both outside colonial law and also underground.

Now "suppose that" Dutch policy had been different, or that the British had colonized the Archipelago, what sort of ideas would Bung Karno have had, and what kind of political career would he have pursued? It is difficult to believe that he would not have felt compelled to participate in general elections, to become a member of the legislature, and very likely eventually Prime Minister-like U Saw in Burma. Even if this meant temporarily being under the supervision of the Governor-General. This supposition is strengthened by his role under the Japanese, which was not significantly different from that of José Laurel, Sr. and of Dr. Ba Maw. ${ }^{12}$ But of course the Dutch were ... Dutch! Quite possibly for just that reason throughout his long life Bung Karno never participated directly or personally in any general election, where he would have had to compete with other native leaders for the people's votes.

In March 1942, the Japanese onslaught destroyed Dutch imperialism in a matter of weeks. Three and a half years later the Japanese imperialists surrendered abruptly and unconditionally after American atomic bombs were dropped on the ill-fated cities of Hiroshima and Nagasaki. The Dutch, who had finally been liberated from Nazi occupation only a few months earlier, were in no condition to make an immediate return to their thrones in the Archipelago-making possible the outbreak of the historic Indonesian Revolution. Here began the gradual process that allowed Bung Karno to imagine himself as the Great Leader of the Revolution. But this imagining would have been out of the question without the brave struggle of the Indonesian people-and also without the stunning "accidents" of March 1942 and August 1945.

In this regard, the attitudes and policies of Bung Karno during the Revolution are of the greatest interest. As is well known, all the cabinets formed between 1945 and 1949-whether led by the socialist-Marxist group or the modernist Muslims and the PNI-took the path of "diplomacy" vis-à-vis the Dutch, even though this path was strenuously opposed by all groups who happened to be out of power at any one time. And President Soekarno? He managed to work cooperatively with almost all groups, and consistently supported the policy of "diplomacy." If we read his speeches from the Revolutionary-era newspapers and magazines-almost none of which were later included in Di Bawah Bendera Revolusi (Under the Banner of the Revolution) [The official, bowdlerized compilation of his major texts, published late in his presidential career]-we can see clearly that aside from rousing Indonesian nationalism, he actually worked hard to calm the turbulence of the masses below-the strikers, the social revolutionaries, the "hard-line" or "obstinate" popular militias, and so forth. Indeed, at the time of the

\footnotetext{
${ }^{12}$ In 1943 these seasoned politicians were appointed by Tokyo as heads of the nominally independent states of the Philippines and Burma. Had the war lasted through 1946, Soekarno would surely have assumed some comparable position.
} 
Madiun Affair ${ }^{13}$ he strongly condemned the New PKI created by Muso, which was far to the left of the previous left-wing of Amir Sjarifuddin, Setiadjit, Maruto Darusman, and Co., and wholeheartedly supported the policy of the Hatta Cabinet and General Nasution to destroy it. After the transfer of sovereignty at the end of 1949, he never, so far as I know, expressed any public regret for the execution of the Republic's second Prime Minister [Amir Sjarifuddin, who held this office from early July 1947 to late January 1948] and his friends. Yet Bung Karno was well-known to dislike killing and other forms of violence.

One can readily see, from the above description of Bung Karno's record during the Revolution, how close his views were to the general outlook of the moderate nationalist leaders. These leaders were certain that the revolutionary military were incapable of decisively defeating the Dutch armed forces on the battlefield. And if this was true for Java and Sumatra, how much truer was it of "East Indonesia?" Therefore Indonesia could only achieve independence via diplomacy (of course with the TNI and the revolutionary militias as a strong card in the diplomats' hand). They also wanted Independent Indonesia to be the sole and complete legatee of the Dutch Indies, from Sabang to Merauke, not just Sumatra-Java-Bali. And what of "East Indonesia"? It should also borne in mind that in those days very few of the national-level leaders had any direct acquaintance with this vast and heterogeneous region. Prior to 1949, Bung Karno had of course been exiled by the colonial government to Flores, but he had never been to Kalimantan, Timor, Sulawesi, Maluku, or Lombok. Hatta and Sjahrir [respectively the infant Republic's first Vice-President and Prime Minister] had been detained on the remote island of Banda and in Tanah Tinggi in West New Guinea/Papua, but otherwise their "social acquaintance" was just as narrow as Bung Karno's. ${ }^{14}$ They could not be sure how strongly Indonesian nationalism had really rooted itself in East Indonesia-except in South Sulawesi, where Buginese and Makassarese took up arms against the reimposed colonial regime, and suffered huge casualties at the hands of Westerling. ${ }^{15}$ Thus: if there was no chance that the Dutch could be expelled from East Indonesia, and if East Indonesia had to be part of the sovereign state of the Republic of Indonesia, there was no choice but to negotiate. This stance of Bung Karno's demonstrates his political realism alongside the famous romanticism of his rhetoric. (One reason why the Irian Barat/Papua Barat/West New Guinea issue was so important for him after 1950 was that he felt that in this regard the policy of diplomacy had failed, thanks to the sly maneuvers of the Dutch and certain groups in Washington. $)^{16}$

\footnotetext{
${ }^{13}$ The so-called Communist rebellion of September 1948 against the Republican government in Jogjakarta. On the left, the affair is remembered as the Madiun Provocation.

14 Here I used the teenage slang term "kuper," short for "kurang pergaulan" referring to a kid who doesn't get around much.

15 The half-Turkish Westerling, a paratrooper famous for his brutalities, killed thousands of people in early 1946 in order to stamp out local resistance.

16 As a result of American pressure, West Papua was "temporarily" excluded from the overall agreement on the transfer of sovereignty over the Netherlands Indies to the government of Indonesia, produced by the Round Table Conference in The Hague at the end of 1949. The agreement stated that the status of West Papua would be settled within a year through bilateral negotiations between The Hague and Jakarta. But the Dutch reneged on this arrangement, arousing great anger in Indonesia throughout the 1950s.
} 
Another key factor in the thinking of Bung Karno and the other nationalist leaders was the emergence of the United States after World War II as the strongest and richest power on "this earth of mankind." Until Chairman Mao's final victory in 1949, there was no power in Asia that could be regarded as a serious competitor. This American dominance was especially relevant for an archipelagic state like Indonesia, through and around which the American navy and air force could roam at will. The Soviet Union was far weaker than the US, and lay many thousands of miles away. Logically, then, Indonesia had to seek Washington's support, not its enmity. It is very plausible that these considerations played a key role in Bung Karno's backing the policy of destroying the New PKI of Muso, who seemed to have suddenly popped up in Indonesia as the envoy of Moscow. ${ }^{17}$

In this context, it is instructive to compare Bung Karno with one other outstanding Southeast Asian nationalist leader, who proclaimed his country's independence almost simultaneously with the Proclamation of August 17, 1945 at 56 Pegangsaan Timur Street in Jakarta. A veteran revolutionary, as well as a patriot, Uncle Ho attempted to carry out both a war for independence and an internal social revolution. Sure that this combination of policies would face the hostility of capitalist America, he ended up affiliating himself with the Soviet Union and Mao's China. His social revolution went ahead, but his nation and his state split into two, and could only be reunited thirty-one years later-after his own death, and after colossal sacrifices by the Vietnamese people that still arouse our sense of horror and admiration.

In 1950-51 Bung Karno was already fifty years old. Perhaps that year marked the real apogee of his political career. He was revered and loved as an open-minded, prudent leader and a fighter for his people from his early youth. Seven years later he was almost killed in the barbarous Tjikini Affair-by a small gang of his own people. There followed many other attempts to assassinate him, and he was finally toppled from office and power by another small gang of his own people. It seems that by the end of the 1950s he had begun to be hated. Why?

Alas, human beings, as they grow old, are usually fated to run out of new ideas and to lose freshness and flexibility in their thinking. Bung Karno was no exception. Over the last ten years of his rule, he created many "new" slogans and "new" concepts. Yet almost all of them can be said to be mere reformulations of his youthful thinking. His speeches were still embellished with quotations from the writings of internationally famous political leaders and intellectuals, but all of these quotations can be found in his speeches and writings of the late 1920s and 1930s. It looks as if Bung Karno no longer had time-and perhaps even interest-in reading. Did he ever dip into the novels and short stories of Pramoedya Ananta Toer, or the poetry of Chairil Anwar? Meanwhile, the world and men's ways of thinking continued remorselessly to change.

\footnotetext{
${ }^{17}$ The veteran communist Muso, who had lived in the Soviet Union since 1935, flew to Indonesia from Communist-controlled Czechoslovakia in disguise, and dramatically revealed his identity on August 11, 1948. He harshly criticized the policies of the existing left-wing parties and pushed through their pell-mell merger into a New PKI with a new radical Program that he called the Djalan Baru, or New Path. How far he was really an emissary of Stalin remains a matter of controversy.
} 
One can surmise that gradually he was "swallowed" up by his own office. In Lukisan Revolusi, the historic photographic record of the revolutionary years, there are many touching pictures of Bung Karno. He is always neatly dressed, but his clothes are quite simple and not far removed from those of the cabinet ministers-some of whom still wore shorts to work. At that time he really was the leader of the revolution for independence. How remote those old pictures are from the public figure of Bung Karno under Guided Democracy! In that era, he usually appeared in a super-elegant quasimilitary uniform, with a dozen ribbons on his chest, and huge dark glasses-even at night. So he became an easy target for malicious foreign cartoonists who made him look like just another reactionary, coup-prone Latin American general. Rather like "Marshal" Tito, and miles away from Uncle Ho. By this time, Bung Karno had become Great Leader of the Revolution.

When he became President-an office without precedent in Indonesia's history, and without any strong traditions as to the scope of its authority-Bung Karno had little real experience to prepare him for the job. He had absolutely no administrative background. He had never been a member of a legislative body. Even with regard to membership in political organizations, such as parties, labor unions, or revolutionary militias, his experience had been fleeting. Possibly he had neither talent for, nor interest in, such activities, which in the modern world are usually the political background for a country's president. For all these reasons, in Indonesia the presidential office has never had clear-cut functions and limits accepted by all citizens. All the more so because of the wretched Constitution of 1945, hastily drawn up under the watchful eyes of the Japanese military dictatorship, and in significant respects modeled on the constitution of China under Sun Yat-sen and Chiang Kai-shek. All these factors opened the door for a syncretism that over time grew more and more dangerous. The function of Head of State-on the level of, say, Elizabeth II-was only too easily jumbled up with the role of national leader-on the level of, say Winston Churchill or Mahathir bin Muhamad. Accordingly authority was confused with power, and over the long haul, the latter superseded the former. What was prohibited to a Head of State was perfectly all right for the Father of the Nation.

In the last years of his rule, one could sense that the subterranean influence of Javanese kingly traditions was steadily growing. This was not just a matter of the multiplication of ostentatiously pompous state ceremonies. In former times, a king was regarded as a unique figure who had personally received the wahju [a ball of mysterious light said to descend on the head of a man destined to be king] from God or Gods; in no way was he merely primus inter pares. And if the wahju stayed with him, the king would automatically become king-for-life. During the Revolution, Bung Karno was still loved as primus inter pares. But afterwards, over time, most of the comrades-in-arms of his generation were marginalized or marginalized themselves. In the end, alas, he was willing to be appointed-by a Provisional MPR whose members he had appointed himself-as President-for-Life: one hundred percent outside the Constitution of 1945. Perhaps it was as early as this juncture that the knell sounded for his time of triumphs: a president-for-life can only be removed by the Angel Gabriel ${ }^{18}$ or by human violence.

\footnotetext{
${ }^{18}$ An allusion to Djibril, the Angel of Death, central to Pramoedya Anana Toer's bitter short story "My Kampung" in the collection Tales from Djakarta.
} 
Two small but significant events demonstrate in exemplary fashion the problems that arise when Head of State, Leader of the Nation, and Maharaja are fused together. The first: Believing themselves to be part of the movement for the emancipation of the human race, the nationalist leaders of Bung Karno's generation generally respected (at least in public) the principle of monogamy, not least in order to raise the status and protect the rights of women. The same principle operated for the majority of Islamic political leaders. One can imagine that if in the 1930s a political activist heard someone predict that eventually Bung Karno would have four wives, he would have felt deeply offended. But after he became President, Bung Karno violated this old norm and became the first top-level leader to practice polygamy. Of course it is true that Islamic traditions permit a man to take four wives, but Bung Karno was not a pious Muslim, and in the eyes of ordinary people his multiple marriages were more associated with the Javanese royal tradition of taking unlimited numbers of wives and concubines. Some people condemned him, some smirked, and others simply shrugged their shoulders. The second comes from my personal experience: In 1963, for various reasons including a failed harvest, famine was spreading in Central Java. I often saw corpses and people more dead than alive sprawled on the sidewalks of cities and towns. Bung Karno's response to this catastrophe was to give a speech inviting hungry people to eat field-mice-"delicious" and "full of vitamins." This invitation was received with widespread cynicism. Not a single person believed that field-mice were a regular feature of the menu at the presidential palace. I was then reminded of the alleged exclamation of Queen Marie Antoinette on the eve of the explosion of the French Revolution. When she got word that the common people were suffering terribly because the price of bread had soared beyond their means to buy it, the Queen, with the naïveté typical of protected aristocratic ladies, exclaimed: "Lho, in that case, why don't they eat kué lapis?" [kué lapis: a gooey sweetmeat made of layers of flavored sticky rice, usually produced for special celebrations] One had the impression that Bung Karno, "protected" by the Tjakrabirawa Regiment (Presidential Security Guard) was by then far, far removed from the daily lives of the poor.

And Bung Karno's nationalism? I imagine no one will deny that Bung Karno's nationalism was deep, strong, and fiery. Yet even nationalism cannot escape the God of Time and the ceaseless change of human history. When Bung Karno was young, most of the population of the Archipelago still lived in their traditional villages and kampongs. No fewer were still illiterate and were raised within local oral traditions. It would have been rare for a man from East Kalimantan to have an Atjehnese friend, let alone to marry his friend's sister. Hence one of the main goals of the nationalist "missionaries" of the period was to make people aware-from Sabang to Merauke - that they were all, together, "Indonesians." Without this awareness, and the broad nationalist movement that developed out of it, there was no possibility of smashing Dutch colonialism once and for all; the dozens of local uprisings that had occurred between 1825-1910 had all been destroyed by Dutch military forces (into which sizeable numbers of natives were always recruited). Without this awareness, the colonial bureaucracy (whose membership in the 1930s was 90 percent native) would remain solidly loyal to the colonial master. Bung Karno understood all this very well, and fought with might and main to spread national awareness, based on the idea of national unity. Those who were "aware" would be able to rise above all the prejudices and narrow-mindednesses passed down from their ancestors. Batak were, yes, 
Indonesians; Hindu Balinese were, yes, Indonesians; followers of Kaharingan beliefs [i.e. the "animist" Dayak of Kalimantan] were, yes, Indonesians; Chinese were, yes, Indonesians; and the same would have to apply even to the proud Javanese. It should be stressed here that this kind of nationalism involved a commitment to action, not merely a new identity. For example, precisely because Protestant Batak and Muslim Minangkabau were very different, and in the past had occasionally been open enemies, "now" a young Minangkabau nationalist had to commit himself to treating Protestant Batak just as he would a fellow Muslim Minangkabau. The same would go for a young Batak nationalist. In fact, the struggle of Bung Karno and his generation was astoundingly successful. Because it smelled too strongly of Java, Budi Utomo gradually faded away. Jong Java, Jong Ambon, Jong Islamieten Bond (which could also be called Jong Minangkabau) (Young Java, Young Ambon, Young Muslim League) all either vanished or merged into Young Indonesia (Indonesia Muda). Ethnic political organizations never throve under the Red-White-and-Blue (Dutch) flag.

But what happened after Indonesia joined the UN and Dutch imperialism was finally kaput ${ }^{19}$ ? With the burden and threat of Dutch dominance gone, Indonesians were finally in a position to manage their collective affairs and to face each other at all levels of society. If we may borrow a famous expression of Bung Hatta, alongside persatuan (unity) there now appeared persatéan (perhaps, disunity, fragmentation).$^{20}$ It goes without saying that this problem did not escape Bung Karno's attention, all the more so in that the young nation-state immediately experienced a series of regional rebellions, almost all of which were led by people who had earlier been active in the nationalist movement and/or the Revolution.

The methods adopted by Bung Karno to overcome these post-independence difficulties are of great interest. In my judgment at least, his decisions were more based on his own earlier experiences and his interpretation of his own multiple roles than on any deep, serious reflection concerning the new situation. For simplicity's sake these methods can be divided into three categories.

The first was to stress the need for an old-style "national-unity" nationalism in the face of external threats: the Dutch, the British, the Americans, and, on a lesser scale, the Malaysians. One can't deny the reality of these threats-within specific limits and in specific instances. But denouncing the Darul Islam and the Republic of the South Moluccas as "merely" puppets of the Dutch, or the PRRI-Permesta as "merely" puppets of the UK and the USA meant closing the eyes to the concrete dissatisfactions of large numbers of Indonesians with the policies of their government. Joining an armed rebellion is not a decision lightly taken-the risks involved are substantial. And if some of these rebels received arms and training from foreigners, the same could be said of the Center. In fact, thousands of officers from the army, the navy, the air force, and the police were trained overseas, and almost all their weaponry came from America or the Soviet Union. Rashly denouncing one's political adversaries as "traitors" and "puppets" does not only make a good resolution of conflicts much harder, but also, in

\footnotetext{
${ }^{19}$ The best I can do for the street slang "kapok."

${ }^{211}$ The expression persatéan comes from saté, the local form of shish kebab, separate chunks of meat skewered together.
} 
fact, diminishes the stretch of nationalism itself. By this time, alas, not all Indonesians were "real" Indonesians any more. Persatean, in fact.

The second and third were actually tied together in a subterranean fashion. During the 1950s, at least until the Tjikini Affair, Bung Karno was very diligent about visiting parts of his country that he had never seen before with his own eyes. In this way he experienced directly the enormous heterogeneity of his people. He was also fully aware that in this vast country there was no "majority" - in terms of ethnicity, ideology, mother-tongue, or religious commitment. (The results of the free election of 1955 proved this perfectly.) Hence there arose any extremely complex, but very concrete problem. How was Bhinneka (Diversity) to be reconciled with Eka (Unity) without the two gravely wounding each other?

Realistic logic, as well as developments in other large and heterogeneous states, should have persuaded Bung Karno that Independent Indonesia would work best as a federal state. The USA had been such from the moment of its birth; Brazil, after the abolition of its monarchy towards the end of the nineteenth century; Nigeria after the horrors of the Biafra War; Germany in the Weimar era and after the fall of Hitler; Smaller India (which was still gigantic) after gaining independence; Yugoslavia, while its fat and cunning "Marshal" remained in power. Had Bung Karno survived up to the present, he would have seen Spain becoming a federal state, Russia too within obvious limits. Srilanka seems headed in the same direction. Even France, famous for its centralizing traditions, is being slowly forced to create space for an autonomous Corsica. Only in China has federalism been completely rejected, with the consequence that the problems of Tibet, Sinkiang, and Taiwan are getting steadily "worse" and more difficult to solve in a good manner.

There are different types of federalism. The components of a federal state can be organized on the basis of administrative traditions, ignoring ethnicity and/or religion.

America is a perfect example of this type. From this standpoint Arizona corresponds nicely with West Nusa Tenggara and Texas with East Sumatra [These are "administrative" provinces covering many different ethnic and religious groups]. They can also be organized on the basis of concentrated ethnic, linguistic, and religious groups, as in Nigeria (the Indonesian parallels would be Atjeh and Bali, for instance). They can even be organized on the basis of a mixture of the above, as in Smaller India. The nice thing about a federal system is that internal political conflicts, which can sometimes be very heated, need not always be "settled" at the national level with an absolute victory for one side over another. A federal system can thus help to mitigate antagonisms, anxieties, and an atmosphere of "it's them or us." Since the bloody Partition of 1947-48, India has been quite stable: no coups d'état and very few dangerous rebellions. For years Communists have governed Kerala and Bengal, while semi-fascists have dominated in Bombay; every major ethnic group has a state of its own, with significant autonomy in running its own affairs. India's federal system took root under the world-class statesman Jawaharlal Nehru, who also actively led the huge Congress Party incorporating many different interests. A powerful civil bureaucracy inherited from British imperialism has also proved a strong stabilizing factor.

And Bung Karno? He rejected any form of federalism and actively participated in the destruction of the Federal Republic of Indonesia established by the Round Table 
Conference in The Hague. Of course, he had good reasons (short term). Between 1946 and 1949 the Dutch had set up many federal states (mostly headed by local feudal rulers or other collaborators) in order to provide a balance against the Republic of Jogjakarta, and, if possible, to destroy it. This is reason why the sound of the word "federalism" rang false in the ears of many Indonesians, and most national-level leaders were profoundly allergic to it. A pity, in fact.

I mentioned earlier that most of the rebellions of the 1950 s were led by people who had earlier been active in the nationalist movement and/or the Revolution. None of these was separatist. (The one exception was the abortive Republic of the South Moluccas, and its leaders were mostly former collaborators.) "Supposing that" a reasonable and healthy federal system had been sincerely set up, it is very likely that many of these rebellions would not have happened. One could imagine further: the PKI governing the state of Central Java, Masyumi ruling the state of West Sumatra, Parkindo [the Protestant Party] in power in North Tapanuli, the Nahdlatul Ulama managing the state of East Java-Madura, the Catholic Party running Flores, the PNI Bali, and even an Atjeh Party in control of Atjeh. In this manner each party would have the chance to learn how to govern well and thereby show nearby states how their residents might fare if such parties were electorally successful there. Of course for such a federal system to work, genuinely free and competitive elections would have to be held every three or four years, and the autonomy of the federal states would have to be fully guaranteed in the constitution. In addition, it would probably have been a good idea-if Eka were to be evenly balanced with Bhinneka-to form a huge, diverse party, along the lines of the Congress Party, led directly by the Father of the Country. Had Bung Karno been prepared to lead the PNI in person and to "go down" to participate directly in the 1955 elections, it is more than likely that he would have won a majority. (Even his daughter later managed to win one third of the national vote!) But Bung Karno decided otherwise. Although he supported and manipulated the PNI (Indonesian National Party, representing secular nationalism of the middle-class variety) from behind the scenes, he did not want to be tightly bound to any organization or institution. He aimed to be the great leader of the entire Indonesian people, not merely of a majority of them. But this was just a dream, as the Goddess of History would demonstrate only too soon. From a certain angle it could properly be said that in this way Bung Karno evaded part of his responsibility as a great leader.

But-and here is the third method-Bung Karno worked in his own way to ensure that some of the useful functions of a federal system (e.g. protecting small minorities) were performed. Himself without racial prejudices, he tried to make sure that Indonesians of Chinese descent had appropriate representation in all civil political institutions right up to the cabinet level. He gave his blessing to, and defended, Baperki, which wanted to have Sino-Indonesians accepted as another among all the different Indonesian ethnic groups. He protected and gave opportunities to the religious minorities too: the adherents of Balinese-style Hinduism, Catholicism, Protestantism, and mysticisms and animisms of different kinds. But exactly there lay

\footnotetext{
${ }^{21}$ Here I used the acronym turba, which encapsulates turun and bawah. The allusion is to one famous slogan of the late Soekarno period, borrowed directly from Maoist lingo. "Going down" meant that students and party elites ought to spend time working with poor peasants to understand their problems and help them solve them, as well as to cleanse themselves of big city pretensions and life-styles.
} 
the difficulty. These groups had to be protected; they had no permanent rights of their own. They were dependent on His Excellency, just as the peasant "little people" had once been dependent on wise Sultans. What all this boiled down to was: these groups were not protected by the law or by the constitution, but only by the person of Bung Karno, who one day would be summoned by his Maker. After he was gone, who or what would protect them then?

Why did he operate this way? Many factors surely played a role, including his allergy to federalism and his fusion of the role of head-of-state + great leader + maharaja.

But probably most fundamental of all was that he had become the victim of his own proud past. After Indonesia became independent, she needed new forms of leadership and a new style of nationalism. Most likely it was precisely his past successes that led Bung Karno to forget this lesson.

The same pattern can be seen in Bung Karno's attitude toward "revolution." Under the conditions of Dutch colonialism, and with Lenin's dictum to hand that the colonies were the weak link in the global imperialist system, it was natural to understand the concept of "revolution" as the uniting of the entire people to destroy Dutch colonialism within the framework of the emancipation of all the peoples of Asia and Africa, indeed of the whole world. It was for this reason that in 1950, after the transfer of sovereignty, Bung Hatta stated that "the [national] revolution is over." (Not only in Indonesia: by the mid-1970s virtually all the weak-link colonies in the world had become members of the United Nations). But Bung Karno would not accept this. He was very proud of the Indonesian Revolution and had no wish to see "revolution" honorably buried as one now-completed task-era in Indonesia's history .

So? The Leninist legacy of his youth impelled him to continue contributing to the global movement of emancipation: but without a firm and steady compass to guide him. For a time he was among the preeminent leaders of the "neutral and independent" bloc between the American bloc and that of the Soviet Union and China: thus "inbetween" the revolutionary states and the counterrevolutionary states. In colonial times, his comrades in this bloc had all been courageous people. But after independence? Nasser and Nkrumah created dictatorships built on lunatic cults of personality, terrorized their competitors, and finally died in despair, with their former reputations in ruins. $\mathrm{U} \mathrm{Nu}$ also built a personality cult around himself, tore the Burmese economy and democratic political system to shreds, and was eventually overthrown by the military. And even though "Marshal" Tito was the one leader in the group who had really been a revolutionary activist in the classical sense, the impending failure of his regime was also perceptible before he died.

Subsequently, Bung Karno launched the concepts of the New Emerging Forces (Nefos) fighting the Old Established Forces (Oldefos) and the Pyongyang-PekingHanoi-Phnom Penh-Jakarta axis. The first was clearly "Lenin's grandchild," but since the world had vastly changed since the 1920 s, no one paid it much attention. The second had nothing to do with Lenin, and showed that the global world of Bung Karno had shrunk down to East and Southeast Asia. Again, without any substantial results in practice. A Greater East Asia Co-Prosperity Sphere without Japan? Feeling, quite rightly, that he was an international figure, Bung Karno convinced himself, quite 
wrongly, that Indonesia could become a major "revolutionary" player in the international arena. But in the face of giants like Japan, China, the European Community, the US and the Soviet Union-as opposed to tiny Holland-Indonesia, with its impoverished people and a state dependent on foreign countries for most of its arms, was effectively impotent. Meantime, José Ramos-Horta and his comrades in East Timor, who expected Bung Karno's help in creating an independent state freed from the clutches of Antonio Salazar's clerico-fascist state, found themselves ignored.

And domestic revolution? At bottom, this was an idea rather difficult for Bung Karno to deal with. This kind of revolution never happens without much blood being spilled between members of the same nation, because it means the overthrow of the ruling class by the classes below, and struggles for that purpose are always violently resisted. The total number of people who perished violently in the Great English Revolution of the seventeenth century, the Great French Revolution of the eighteenth century, and the Great Revolutions in Old Russia and China in the twentieth century is incalculable. Civil war of this kind, one suspects, was in sharp contradiction to Bung Karno's syncretic nationalism, to say nothing of his humanity.

At the same time, it would not be fair to say that Bung Karno did nothing to transform the social-economic structures inherited from the colonial period. Yet, generally speaking, all of his endeavors failed, partly because of his own imprudence, and some even boomeranged against him. The nationalization of all Dutch enterprises at the end of 1957-when Indonesia was already under martial law-was not only carried out hastily and without adequate planning, but resulted in all the most advanced sectors of the Indonesian economy falling willy-nilly into the hands of the army. Thereafter, the trade unions in these advanced sectors were paralyzed by the new bosses, and the enterprises themselves were typically so mismanaged that their productivity fell like a stone thrown into a well, to say nothing of the quiet looting of their assets by crooked officers. Indonesia's economic disaster in the 1960s actually began in December 1957. "Supposing that" the nationalizations had been carried out gradually and in a well-planned way during the liberal democratic period, would their consequences have been so tragic?

The Agrarian and Crop-sharing Laws of 1960-61 had the excellent goals of eliminating big landlords, distributing land to rural laborers, and enforcing a fair division of harvests between tenants and landowners. But crucial exceptions were made for: 1.) the very extensive tanah lungguh (appanage land) attached to village headmanship from feudal times; and 2.) land owned by religious institutions. Plenty of people owning acreage above the new legal limit transferred the excess land to religious bodies (on the boards of which they often sat). The unanticipated result was that in the grave agricultural crisis of the early 1960s, the identification of big landownership with religious institutions (Islamic, Christian, and Hindu-Balinese) grew perilously strong. The national leadership also failed to consider the timing of the new laws. By then inflation was beginning to soar out of control, and the value of the rupiah fell week by week. People no longer had any confidence in the currency and hurried to get hold of concrete "goods," including land, instead. This behavior was particularly rife among bureaucrats who felt that their fixed, monetary salaries had lost most of their value. Especially officials in the ministries of the interior and of agrarian affairs, as well in the public prosecution, the police and the army, moved quietly to expand the 
acreage they owned and to block any serious endeavor to enforce the laws. Unsurprisingly, the PKI then launched its "unilateral" mass actions to overcome the sabotaging of the laws' implementation, and, no less unsurprisingly, this campaign failed in the midst of rapidly sharpening tensions in the rural communities. The massacres of 1965-66, in which tens of thousands of ordinary rural people came to be executioners, cannot be fully explained without reference to the social, economic, and psychological consequences of a land reform program put into place under conditions of uncontrolled inflation, as well as martial law. "Supposing that" the program had been launched under the relatively stable socio-economic conditions of the liberal democratic period, would not the outcome have been quite different?

It is necessary also to emphasize very strongly that incessantly using fiery "revolutionary" rhetoric unaccompanied by practical, concrete, and well-thought-out policies for achieving this rhetoric's stated goals was like revving up a motor car's engine to maximum speed without putting it into gear. The engine gets burning hot, but the car does not move. Towards the end of Guided Democracy the atmosphere in Indonesia was getting more and more heated, while the sedan brand-named Progress, let alone the pickup brand-named Revolution, stalled and broke down. This spectacularly visible contrast increasingly eroded Bung Karno's authority. The "prorevolution" groups grew more and more frustrated at the lack of concrete progress, while for the "antis" the specter of revolution aroused deeper and deeper panic and fury. Did Bung Karno really understand this situation? This is not an easy question to answer. But it is equally difficult to avoid the conclusion that if Bung Karno was a great leader in the era of Revolution for Independence, which exploded from below, quite outside the calculations of the Nationalist Movement's elite, he absolutely cannot be called a Great Leader of (The) Revolution fullstop.

In the too lengthy analysis above, I have tried to understand Bung Karno as a man of his time-a time that has long passed-not to praise him or to condemn him either. The Father of the Indonesian Nation is today immune both to praise and blame. He was shaped by his birth, by his education, by the history of the Netherlands Indies, and the history of the modern world: also by the sweet and bitter experiences of his youth. Yet in the end all these factors cannot explain why this HBS and ITB graduate made the decision to become a fighter for his country's freedom (at a time when the Dutch colonial state seemed so powerful and so permanent) rather than a quiet, successful professional architect. After the horrors of the Orde Babibuta, it may be too easy to say: "Well, at least he was never tortured, his wife was never raped, and his children were never socially ostracized as anak haram politik. ${ }^{23}$ Nor was the property he owned ever seized." All this is true enough, but he was spied on, menaced, slandered, ridiculed, tried by a sort of colonial Mahmilub, ${ }^{24}$ and lost his freedom for almost ten years. If Japan had not overrun the Netherlands Indies, his internment could

\footnotetext{
${ }^{22}$ Babibuta, literally "blind boar," means to "rage savagely." This is my riff on Orde Babe, the standard slang term for Suharto's Orde Baru.

${ }^{23}$ Here I make an oblique allusion to Pramoedya's famous short story "Anak Haram." The term usually means "illegitimate child," but Pramoedya used it to refer to the ostracized status of a young boy whose father had been a collaborator with the Dutch.

${ }^{24}$ An allusion to the kangaroo-court Extraordinary Military Tribunals set up try communists from late 1965 on.
} 
have continued for years into his old age. He loved the heterogeneous nation that he himself had helped to build. More than anyone else in his generation he had the ability to spread national consciousness and the ideals of freedom even to the poorest of the poor. Such intimate ties with his people, combined with his other gifts, meant that at the time of the Proclamation of Independence in 1945 no other native but he was imaginable as the country's first head of state. It's true: he was really loved.

As leader of the movement for national independence he was an outstanding success. But it has to be admitted that as state leader in the post-independence era, he was a failure in many respects. His Guided Democracy collapsed into smoking ruins, and he ended his life once again as a prisoner. In all this he was by no means unique. Many other heroes of different independence movements failed as presidents or prime ministers in the aftermath of independence: $U$ Nu, Nasser, Sekou Touré, Nkrumah, Bandaranaike, Mugabe, Kim Il Sung, and Kenneth Kaunda, among others. Sun Yat-sen too. And if Gandhi had not been assassinated, but had become Head of State, would he have been a success? Not necessarily. Could Ho Chi Minh have ever imagined that thirty-three years after his death, his Vietnam would be listed as World No. 1 or No. 2 for corruption, which spread like cancer through its body politic? The challenges of the post-independence period are very different from those of the heroic period that precedes it. And the world also changes constantly at a dizzying speed.

In all this are there any useful lessons to be learned for our own time? Perhaps there at least two. The first is the danger of fossilization. If there is some truth in my lengthy analysis, the conclusion can be drawn that with respect to Bung Karno's attitudes and thinking the fossilization process began with Bung Karno himself once Indonesia had become independent and he had become president. By stages, of course. And after his death, this fossilization has only increased apace, under clouds of incense. Such a conclusion does not mean that Bung Karno's views and values are totally out of date. It simply means that his thinking needs to be considered in a critical (not hostile) spirit, on the basis of a historical awareness of the distance between his time and our own. The Borobudur, the largest and maybe the most beautiful Buddhist stupa in the world, is today a source of pride for the Indonesian people. But today's Indonesian society is no longer Buddhist. The Buddhism which inspired the creators of the Borobudur more than a millennium ago interests almost no one in the Archipelago today. Yet the stupa's grandeur, its beauty, and the solemnity that surrounds it still inspire and awe.

Treating the writings of Bung Karno as a Holy Book (like the Bible or the Koran) or as Sacred Ancestral Teachings makes impossible any deep and relevant thinking about the problems facing Indonesia today: creating social justice in the era of globalization and computerization; developing a healthy federal system in which Bhinneka and Eka do not have knives at each others' throats; finding alternatives to the savagery of neoliberalism, the octopus-grip of gigantic "transnational" corporations, and the nihilism of Hollywood; stopping the destruction of the environment; providing protection for minorities; securing human rights, and, still more important, the rights of Indonesians as citizens of Indonesia; battling the total rot in the country's legal system; and so many more. For most of these problems, no answers will be found in The Teachings of Bung Karno. Times have changed so much, so fast.

To the contrary, fossilization opens the door wide to manipulation and deception. Crooked politicians can win mass support by claiming to be " 100 percent Faithful to 
Bung Karno's Teachings," while actually pursuing policies and programs 100 percent in violation of Bung Karno's principles. Most of the leaders of the PDIP [Indonesian Democratic Party of Struggle, headed by Bung Karno's daughter Megawati Sukarnoputri] have accommodated themselves to the neoliberal capitalism insisted upon by the IMF and the United States, while quietly tossing into the garbage-bin any conception of socialism, including Bung Karno's Indonesian-style Socialism. These people do not have the courage to say frankly "We reject Bung Karno's socialist principles as both mistaken and out of date." The same people fully supported Harto's colonial policy towards East Timor, rather than helping the East Timorese in their struggle for freedom. This stance did not merely violate the Constitution, which describes in detail the country's geographical extent as inherited from the Netherlands Indies; it also represented a shameful 100 percent about-turn from one main principle of Bung Karno's nationalism-world-solidarity with all nationalist movements in fighting colonialism. Any Sukarnoist with a brain in his head can see that in the drama of East Timor, the old role of the Dutch colonialists was taken over by the Indonesian government, while Bung Karno's former role was played by Xanana Gusmão. In this instance, too, the PDIP leaders were too cowardly to say publicly that "Bung Karno was wrong," let alone give any rational reasons for saying so. Praising The Teachings of Bung Karno to the skies while quietly betraying their most central components represents a dishonesty and a hypocrisy that is very ominous for the future.

Second: From Bung Karno and his time we can disinter the seeds of a vitally needed form of nationalism, not as an heirloom inherited from the ancestors, but as a political commitment in the present and for the future. It is true that he often spoke facilely about 350 years of Dutch colonialism, though he knew perfectly well that at the time of his own birth Atjeh, South Bali, and most of South Sulawesi had yet to be subjected to imperialist control. It is likely, however, that he used such language to make his listeners feel ashamed, and because of this sense of shame, feel prodded into action. He knew just as well that even Kartini, dying so young, had no opportunity to feel herself an Indonesian woman. Bung Karno's generation was the first to imagine itself as "Indonesian." Thus being Indonesian was (and is) not something "natural" or biological, but was (and is) something created by modern history, and demands determination, solidarity, a willingness to make sacrifices, and hope. Above all, hope. The "Indonesian" imagined by the National Movement was a human being who stood up straight, didn't grovel to, and didn't trample on, anyone, and was open-minded, dynamic, inclusive, steadfast in adversity, and with sympathy for all mankind. A human being of this kind is not a creature who appears in the world "naturally," but needs to be trained, day in day out, both by him- or herself, and by his or her fellow human beings. This, I think, is the most important of those "lessons" from Bung Karno that are still fresh and relevant for his countrymen. And: an unbreakable optimism, even amidst ruin. Requiescas in Pace, Bung Karno. 
